\title{
СТРУКТУРНО-ФУНКЦІОНАЛЬНІ КОМПОНЕНТИ ДИДАКТИЧНОЇ МОДЕЛІ ФОРМУВАННЯ СОЦАЛЬНОЇ КОМПЕТЕНТНОСТІ СТУДЕНТІВ
}

Качалова Т. Г. Структурно-функціональні компоненти дидактичної моделі формування соціальної компетентності студентів.

У статті уточнено поняття соціальної компетентності, визначено компонентну структуру соціальної компетентності студентів та змістове наповнення кожного 3 функціональних компонентів.

Ключові слова: компетентнісний підхід, компетентність, соціальна компетентність, компонентний складник.

Качалова Т. Г. Структурно-функциональные компоненты дидактической модели формирования социальной компетентности студентов.

В статье уточняется понятие социальной компетентности, определяется компонентная структура социальной компетентности студентов и содержательное наполнение каждого из функциональных компонентов.

Ключевые слова: компетентностный подход, компетентность, социальная компетентность, компонентная составляющая.

Kachalova T. G. Structural and functional components of a didactic model of forming students' social competence.

The author gives the concept of the social competence as well as defines the component structure of students' social competence and substantial content of each of its functional components.

Key words: competence approach, competence, social competence, components.

Особливості сучасного етапу розвитку та становлення людської цивілізації пов'язані 3 загостренням комплексу ключових проблем суспільства. Серед них економічні, енергетичні кризи, а також соціальні та національні конфлікти. У структурі особистості починають домінувати прагматизм, духовний занепад. Спеціалісти запевняють, що джерела дефіциту духовної культури слід шукати насамперед у вадах освітньої системи. Ця обставина $є$ поштовхом задля пошуку шляхів реформування освіти, яка на сучасних теренах не виправдовує свого громадського призначення.

Глобальна інтенсифікація постіндустріального життя соціуму спонукає науковців усіх прогресуючих країн світу шукати нові парадигми реформування освіти, iї нові моделі і технології. Досліджуючи соціальне замовлення суспільства, розуміємо, що модернізація змісту освіти вищої школи має бути спрямованою на підготовку висококваліфікованого компетентного у своїй галузі спеціаліста [5; 6].

Компетентнісний підхід- реальність нашого соціального життя, освітньої політики та процесу професійної підготовки студентів. Орієнтація на засвоєння вмінь, способів діяльності була одним із важливих аспектів дослідницької діяльності таких вітчизняних науковців, як: Н. Бібік, Л. Ващенко, О. Локшина, О. Пометун, О. Савченко, С. Трубачева та ін.

Проблему формування компетентності досліджували І. Зазюн, А. Хуторський, А. Маркова, О. Овчарук, О. Пометун та ін. Слід виокремити у психолого-педагогічній літературі цінні наукові дослідження 3 проблеми формування соціальної 
компетентності С. Бахтєєвої, Н. Білоцерківець, С. Демченко, I. Зимньої, Є. Коблянської, С. Краснокутської, Л. Лєпіхової, А. Маркової, В. Сластьоніна, Л. Сохань та ін.

Реалізація компетентнісного підходу в освітньому процесі передбачає дотримання низки дидактичних умов. Перша з них полягає в чіткому усвідомленні учасниками навчального процесу дидактичної специфіки, закладеної в поняття «компетентність» як педагогічної категорії, яка може характеризувати як певний етап в освітньому процесі, так і його кінцевий результат - результат освіти. Другою умовою $\epsilon$ чітке визначення вимог до кінцевого рівня сформованості базових (ключових) компетенцій суб'єктів навчання та до основних етапів їх формування. Наступною взаємопов'язаною $з$ попередніми дидактичною умовою $є$ послідовність реалізації компетентнісного підходу на різних етапах та рівнях формування змісту освіти [3, с. 51].

У світовій освітній практиці поняття компетентності $€$ одним з центральних, тому що, по-перше, об'єднує у собі інтелектуальний і діяльнісний складники освіти; по-друге, у понятті компетентності закладено етапність отримання освіти 3 орієнтацією на сформований стандарт її результату; по-третє, ключова компетентність має інтегративну природу, оскільки містить низку однорідних чи споріднених умінь та знань, що належать до широких спектрів культури і діяльності (інформаційної, правової тощо).

На думку сучасних педагогів, набуття життєво важливих компетентностей може дати людині можливості орієнтуватись в інформаційному просторі, швидкоплинному розвиткові ринку праці, подальшому здобутті освіти. Виходячи з грунтовного аналізу численних досліджень, міжнародні експерти окреслюють основні критерії, які $\epsilon$ засадничими для визначення та відбору ключових компетентностей, а саме:

- $\quad$ ключові компетентності сприяють результатам високого рівня, зокрема й соціального рівня на шляху до успішного життя та розвиненого суспільства;

- ключові компетентності $€$ відповідними засобами щодо важливих, складних потреб і викликів у широкому контексті;

- $\quad$ ключові компетентності є важливими для особистості [3, с. 45].

Усі ключові компетентності $\epsilon$ соціальними, тому що вони виробляються, формуються, виявляються i розвиваються в соціумі, а також характеризують взаємодію людини з іншими людьми, суспільством у цілому.

Соціальна компетентність $\epsilon$ необхідною умовою успішної діяльності майбутнього фахівця, що передбачає засвоєння соціальних знань, умінь і навичок, необхідних для виконання соціальних функцій, які знімають відчуття внутрішнього дискомфорту й блокують можливість конфлікту із соціальним середовищем.

Як зазначає О. Мачехіна, соціальна компетентність представлена множиною соціальних компетенцій. У перекладі з латини competentia означає коло питань, у яких людина обізнана, володіє пізнанням і досвідом, відповідно виконує соціальні дії [6, с. 37].

У процесі побудови дидактичної моделі формування соціальної компетентності студентів нами виявлені концепції: проект людської діяльності (Г. Судольський); системно-рольову модель формування особистості (Н. Таланчук); створення сприятливих умов формування соціальної компетентності в умовах освітнього простору (О. Безпалько) [1, с. 37].

Дидактична модель формування соціальної компетентності студентів, що нині розробляється нами, складається 3 п'яти парціальних компетенцій: когнітивної, інтерактивної, операційної, імплементаційної та рефлексивної, які формуються 
засобами сучасних освітніх технологій під час навчання гуманітарних дисциплін i цілеспрямовані на розвиток умінь і навичок студентів розв'язувати комплікативні соціально значущі ситуації 3 метою збагачення їх соціально-особистісної самореалізації.

Науковець С. Остапенко вважає, що структура соціальної компетентності $\epsilon$ своєрідним синтезом психолого-педагогічних, соціологічних напрацювань у поєднанні з сучасними досягненнями гуманітарних наук [4, с. 188].

Важливим структурним елементом моделі формування соціальної компетентності $€$ визначення іiі основних функцій: інформаційно-пізнавальної, адаптивної, прогностичної, комунікативної, рефлексивної, поведінководіяльнісної [3].

У нашому дослідженні розуміємо соціальну компетентність як інтегрований комплекс ключових парціальних компетенцій, що уможливлює обгрунтування складу iii компонентів. Аналіз наукових досліджень соціальної компетентності говорить про певну усталену логіку компонентної структури останньої. Так, когнітивний i мотиваційний як обов'язкові у структурі соціальної компетентності компоненти виокремлюють І. Зарубінська, С. Остапенко, Л. Свірська; додають комунікативний складник В. Радул, С. Нікітіна, В. Цвєтков; дослідники С. Краснокутська, С. Зільберман уводять змістовий (соціальні знання) та операційний (володіння технологією діяльності) компоненти.

На основі вивченого та узагальненого наукового матеріалу визначаємо чотири функціональні компонентні складники дидактичної моделі формування соціальної компетентності студентів: мотиваційно-особистісний, партисипативно-діяльнісний, імплементаційно-управлінський та рефлексивний.

Мотиваційно-особистісний компонентний складник містить соціальні знання, соціально-пізнавальну спрямованість студента, соціальні установки, наповнює когнітивну компетенцію у моделі формування соціальної компетентності студентів і містить пізнавально-оціночну діяльність, яка забезпечує цілісність навчального процесу, а також активізує зазначену діяльність, сприяє розвитку і збагаченню компонентів когнітивного досвіду. Ефективне формування когнітивної компетенції забезпечує зберігання в пам'яті, відтворення в потрібний момент задля розв'язання теоретичних і практичних завдань інформацію.

Партисипативно-діяльнісний компонент: соціальні уміння і навички суб'єктів навчального процесу для вирішення психолого-педагогічних задач, соціальна активність. Компонент зумовлюється набором знань, умінь і навичок, що дають змогу студенту у процесі активної взаємодії ефективно і якісно виконувати певну навчальну діяльність, використовуючи та набуваючи досвід, постійно удосконалюючи вже наявний комплект знань, умінь і навичок.

Імплементаційно-управлінський складник: соціально-прогностичні уміння, творчий підхід у використанні активних та інтерактивних продуктивних технологій навчання. Компонент характеризується прагненням i здатністю студентів реалізовувати свій потенціал (знання, уміння, досвід у використанні різноманітних технологій навчання) для успішної творчої діяльності у соціальній сфері, а також усвідомленням значущості особистої відповідальності за результати цієї діяльності та необхідності у іiі постійному вдосконаленні. І. Зарубінська зазначає, що застосування саме інтерактивних методів навчання сприятиме розвитку ефективної міжособистісної взаємодії. Використання інтерактивних технологій навчання актуалізують ситуативні мотиви діяльності; активність, умотивована цими спонуками, веде до формування усталених мотивів і цінностей, що перебувають у семантичному 
полі соціальної компетентності особистості [2].

Рефлексивний компонент: самоаналіз соціальної діяльності, саморозвиток особистості. Властивістю компонента $\epsilon$ здатність до осмислення основ своєї діяльності, в ході якого здійснюється оцінка і переоцінка своїх здібностей, особистих досягнень; свідомий контроль результатів дій, аналіз реальних педагогічних ситуацій. Містить здатність до саморозвитку особистості.

Отже, аналіз психолого-педагогічної літератури засвідчує, що теорія, принципи та методика формування соціальних знань, умінь і навичок потребує грунтовних досліджень на різних структурних рівнях. Застосування компетентнісного підходу, інтерактивних технологій навчання й діяльності студентів у сучасному соціальному середовищі передбачають особистісно-діяльнісну спрямованість навчання.

Соціальна компетентність формується завдяки структурованим ключовим компетенціям (когнітивна, інтерактивна, операційна, імплементаційна, рефлексивна), кожна 3 яких наповнена визначеним переліком здібностей суб'єкта навчального процесу. Описано мотиваційно-особистісний, партисипативно-діяльнісний, імплементаційно-управлінський та рефлексивний компонентні складники дидактичної моделі формування соціальної компетентності студентів.

Відкритими для подальших розвідок залишаються питання ефективного застосування інтерактивних технологій навчання у процесі формування соціальної компетентності студентів.

\section{Література}

1. Бойчук П. М. Модель формування соціальної компетентності студентів педагогічних коледжів / М. П. Бойчук, Н. В. Борбич // Соціальна педагогіка: теорія і практика. - 2013. - № 1. - С. 35-43. 2. Зарубінська І. Б. Проблема діагностики соціальної компетентності студентів вищих навчальних закладів / І. Б. Зарубінська // Інформаційні технології й засоби навчання. - 2009. - № 5 (3). - Режим доступу до журналу: www.ime.edu-ua.net 3. Компетентнісний підхід у сучасній освіті: світовий досвід та українські перспективи: Бібліотека освітньої політики / за заг. ред. О. В. Овчарук. - К. : К.І.С., 2004. - 112 с. 4. Остапенко С. Компонентна структура соціальної компетентності студентів філологічних спеціальностей / С. Остапенко // Вища школа. Спецвипуск № 8. - Ч. 1. - С. 187-194. 5. Слєпкань 3. І. Наукові засади педагогічного процесу у вищій школі: [навч. посіб.] / 3. І. Слєпкань. - К. : Вища школа, 2005. - 239 с. 5. Стратегії модернізації змісту вищої освіти: матеріали для розробки документів 3 оновлення загальної освіти. - К. : ТОВ «Світ книги», 2001.95 c. 6. Rychen D.C. et al. Key Competencies for Successful Life and Well-Functioning Society. - OECD: Hogrefe and Huber, 2003. - 224 p.

УДК 371.315.6: 372.4

Олена Ковшар

\section{ОСВІТА ЯК ПЕДАГОГІЧНА КАТЕГОРІЯ В КОНТЕКСТІ ГЛОБАЛІЗАЦЙ І ВИКЛИКІВ ЧАСУ}

Ковшар О. В. Освіта як педагогічна категорія в контексті глобалізацій і викликів часу.

У статті автор пояснює феномен «освіта», з позицій якого можна максимально сприяти соціалізації людини, ii оптимальній адаптації до життя в суспільстві; визначає важливість глобалізації та модернізації сучасної освіти, акцентує увагу на принципах, функціях та підходах іiі організації.

Ключові слова: освіта, освіта як процес, глобалізація освіти, функції сучасної 